\title{
Connessioni digitali per la salvaguardia dell'architettura di pregio
}

\author{
Carlo Giannattasio
}

\section{Abstract}

II processo di ricostruzione e recupero dei contesti architettonici storicizzati richiede un attento studio delle singole architetture che li compongono. Le ricerche documentali devono essere affiancate da molteplici campagne di rilievo per una più accurata definizione dello stato conservativo del manufatto. L'acquisizione massiva di dati eterogenei può però risultare vana, se non vengono definite adeguate procedure di archiviazione e gestione delle informazioni. Si vogliono qui presentare alcuni risultati preliminari relativi alle ricerche condotte sul complesso di Santa Maria degli Angeli alle Croci, edificio sito nella città di Napoli. In particolare, dopo aver delineato le trasformazioni subite dall'edificio, vengono analizzati lo schema compositivo e lo stato conservativo degli affreschi presenti nel chiostro. Si vuole infine porre l'attenzione sulla necessità di avere sistemi di database relazionali e delineare un processo che coinvolga l'uso combinato della metodologia BIM e GIS.

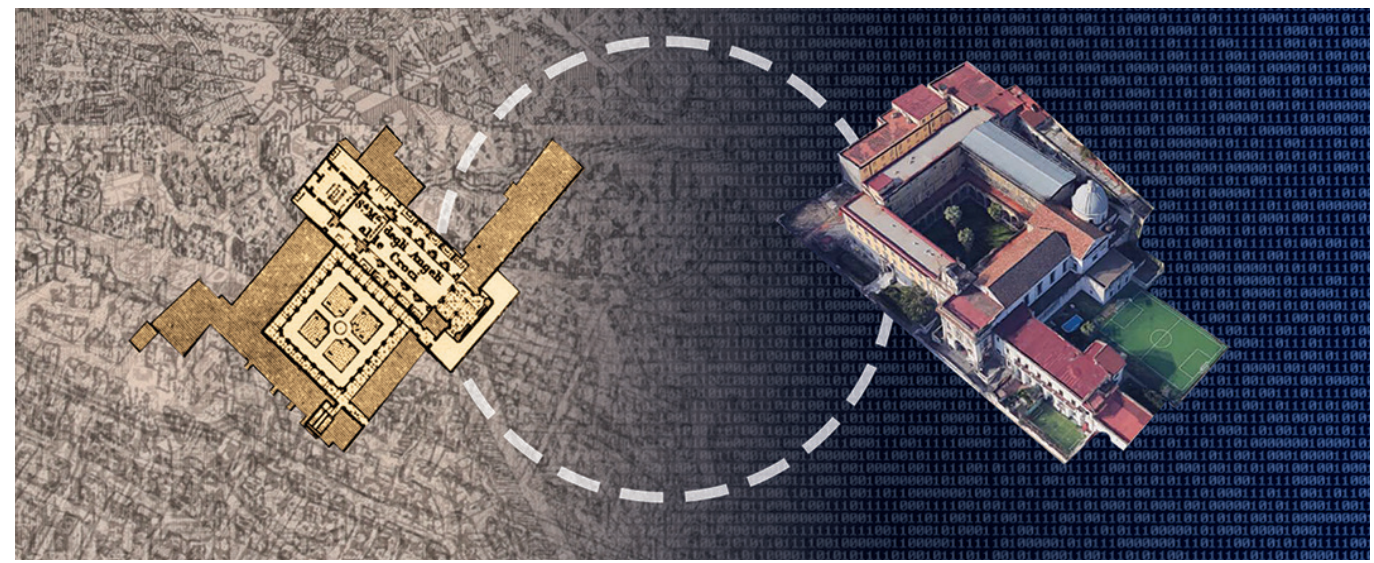




\section{Introduzione}

La continua trasformazione del tessuto edilizio delle città ha portato alla creazione di edifici stratificati e le tracce di alcuni di essi rischiano di perdersi se non documentate e preservate adeguatamente. Le continue modifiche, strutturali e funzionali, possono infatti portare al danneggiamento e alla scomparsa di reperti, con il rischio che essi diventano poi irrecuperabili. Con le nuove tecnologie digitali è possibile collegare le conoscenze e creare dei database, nei quali raccogliere tutte le informazioni acquisite e condividerle. Seppure solo in via digitale, la ricostruzione di questi luoghi ha infatti lo scopo di creare un punto di partenza per un processo di sensibilizzazione; la diffusione delle ricerche infatti può innescare un processo di recupero dei complessi e dei piccoli centri. Diviene quindi fondamentale una adeguata procedura di archiviazione e gestione dati, che successivamente potranno diventare il punto di partenza per i successivi interventi, siano essi di natura strutturale o solo comunicativa. Lo studio qui presentato vuole presentare l'evoluzione di un manufatto architettonico, sito nella città di Napoli. In particolare, il lavoro ha interessato il rilievo e l'analisi degli apparati decorativi del complesso di Santa Maria degli Angeli alle Croci; parte dell'edificio è attualmente sede della facoltà di Veterinaria dell'Università degli Studi di Napoli Federico II. Si è voluto inoltre delineare un processo di archiviazione e gestione dati attraverso l'uso di un sistema di database relazionali.

Fig. I. Individuazione del complesso di Santa Maria degli Angeli alle Croci su grafici storici: a) Veduta del 1685 [de Seta 1969 $X V I I]$; b) Veduta del 1720 [de Seta 1969, XXIII]; c) Pianta di Gravier de 1775 [de Seta 1969, XXVIII]; d) Pianta del duca di Noja del 1775 [de Seta 1969, vol III].

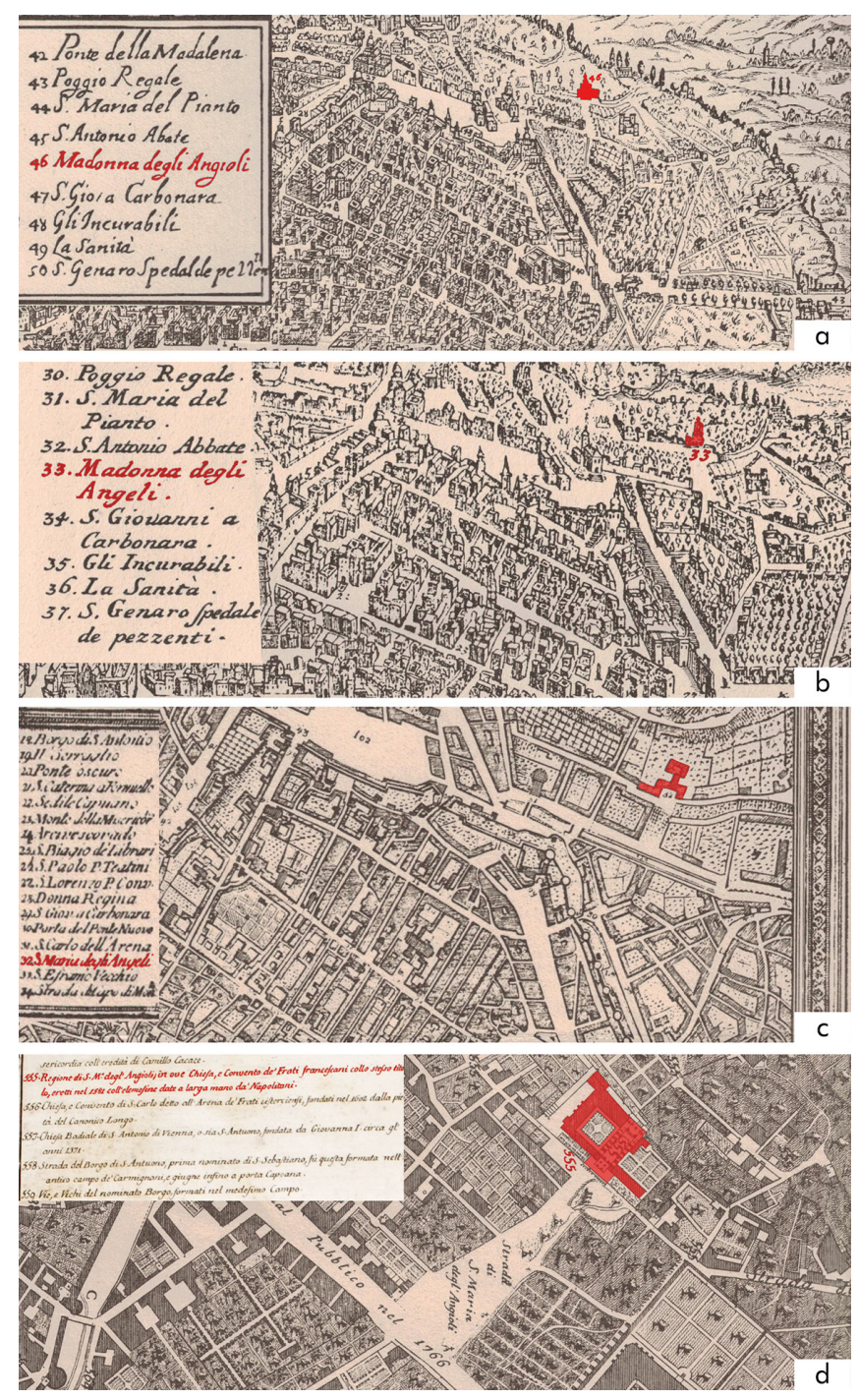




\section{Evoluzione storico-compositiva dell'edificio}

Santa Maria degli Angeli alle Croci nasce alla fine del XVI secolo, epoca durante la quale Napoli è stata oggetto di numerose modifiche. Nella prima metà del I 500, la città ha subito una considerevole espansione demografica, continuata poi nella seconda metà, seppure in maniera più modesta. Questo ha portato ad un accrescimento extra moenia della città, principalmente ad opera di facoltosi privati o di differenti ordini religiosi. In questa espansione, sorge il complesso di Santa Maria degli Angeli alle Croci, per volontà dei Francescani Osservanti, che comprende una chiesa ed un convento [de Seta 1969, pp. I21-137]. Esso è ubicato al di fuori dei confini cittadini, a nord est, insieme ad altri nuovi complessi religiosi e non. II manufatto architettonico viene restaurato verso la fine della prima metà del I600 (1639- 1647), ad opera di Cosimo Fanzago. È fondamentale sottolineare la partecipazione di Belisario Corenzio e della sua bottega ai lavori: ad essi, infatti, viene affidato il compito di affrescare il chiostro interno del convento [Pugliese Caratelli I994, pp. 356-38 I]. Se nelle vedute del I 600 e del 1720 è visibile una prima raffigurazione dell'edificio, si possono ottenere più informazioni sulla sua conformazione dalle piante di Gravier ma soprattutto da quella del duca di Noja (fig. I). All'inizio del XIX secolo, Napoli subisce una serie di trasformazioni, tra cui la soppressione napoleonica degli ordini religiosi: con questo provvedimento, alcuni beni posseduti dalla chiesa vengono adibiti a nuova funzione. II complesso di Santa Maria degli Angeli alle Croci ricade tra questi: la chiesa resta in gestione ai frati, ma il convento diviene un istituto di Veterinaria, con insegnamenti teorici e pratici [Fratta 2004, pp. 299-32 I].
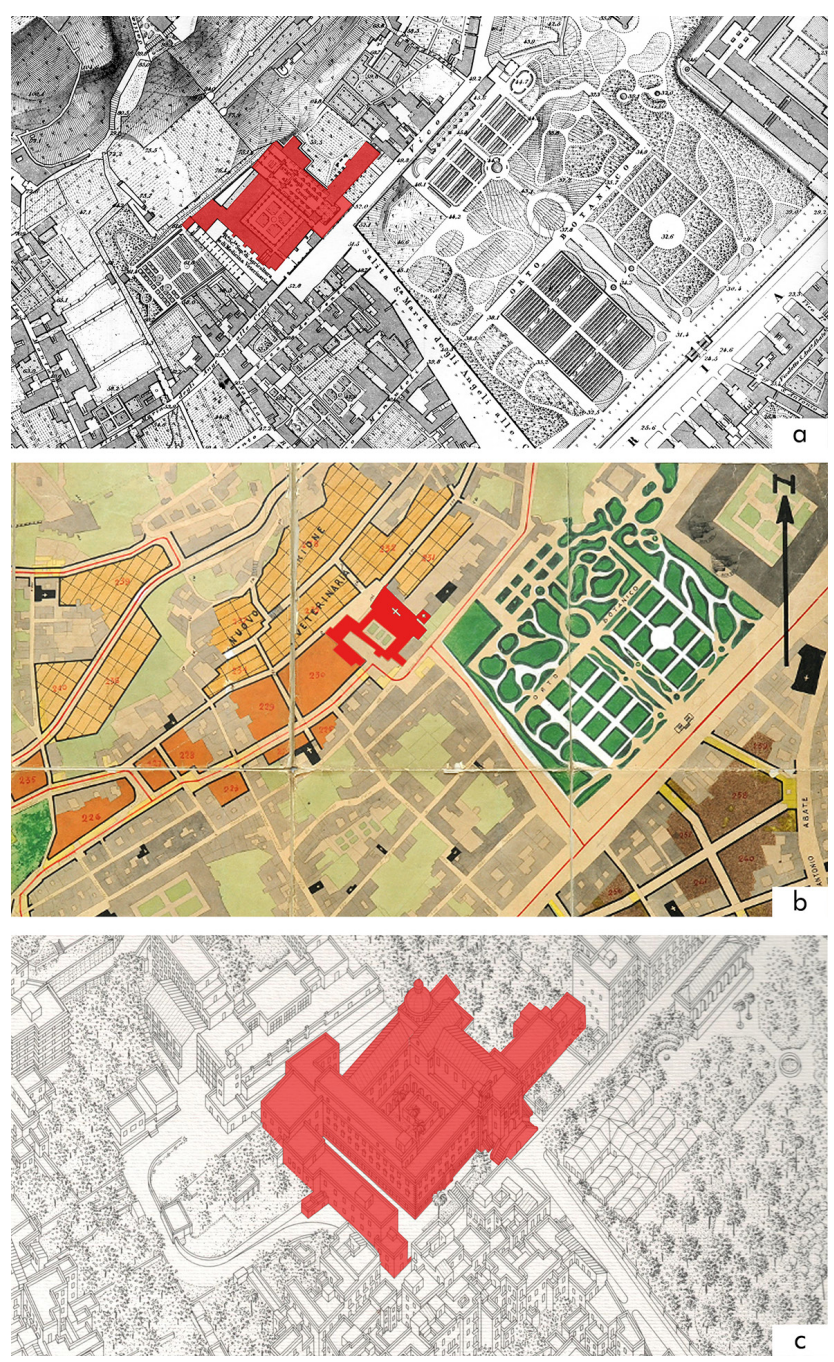
Questa modifica di destinazione d'uso viene anche riportata anche più tardi nella pianta dello Schiavoni (fig. 2a) che distingue la chiesa dalla Reale Scuola Superiore di Agricoltura e di Medicina Veterinaria. Nella prima metà del 1900, si susseguono quindi lavori di ampliamento e di ammodernamento della struttura, come si può vedere anche dalle tavole del PRG del 1939 (fig. 2b): nello stesso periodo, esso viene annesso all'Università degli Studi di Napoli Federico II. Negli anni che seguono la Seconda guerra mondiale, vengono effettuati ulteriori ampliamenti in corrispondenza dell'area precedentemente adibita alle stalle. La sua immagine resta pressocché immutata, finché nel dicembre del 2015 parte dell'ala moderna crolla per un cedimento del sottosuolo. L'attuale conformazione del manufatto architettonico può essere quindi divisa in tre parti: la chiesa, l'ex convento e l'ala moderna. L'edificio ecclesiastico si sviluppa su un'unica navata centrale, ai lati della quale sorgono alcune cappelle voltate; essa non presenta però particolari elementi di pregio o decorativi al suo interno. II blocco universitario presenta una struttura eterogenea, che dipende dall'epoca di costruzione dei singoli edifici. Sviluppandosi su quattro livelli, l'ex convento conserva le tracce della struttura originale, anche se ha subito numerose trasformazioni: il chiostro rappresenta ancora oggi il fulcro attorno al quale si sviluppa l'edificio. Questo elemento è rimasto pressocché immutato, come testimoniato dalle planimetrie storiche e dagli elementi costruttivi (strutture in muratura e coperture su volte). Sempre su quattro livelli, l'ala novecentesca si adegua al volume preesistente; rispettando però i dettami del tempo, la struttura è composta da elementi intelaiati in calcestruzzo armato.

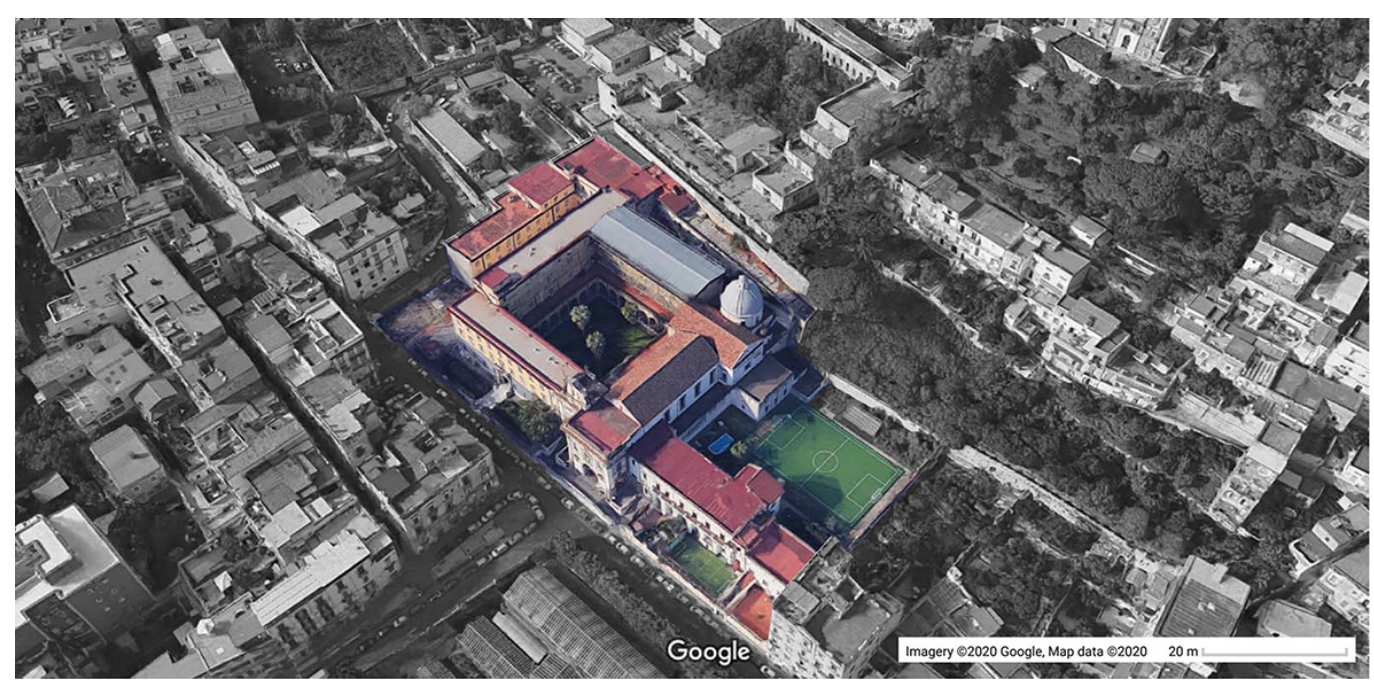

\section{Descrizione delle attività di rilievo}

In seguito al tragico evento del 2015, l'ufficio tecnico dell'università ha manifestato la necessità di aggiornare e dettagliare i grafici contenuti in archivio; i dati in loro possesso infatti non riuscivano a descrivere la complessità architettonica del manufatto. Gli elaborati tecnici sono però risultati utili nella programmazione e progettazione della attività di rilievo; è stato quindi svolto un primo sopralluogo perlustrativo, per individuare le zone da cui iniziare. Le analisi precedentemente condotte e le necessità conservative degli apparati decorativi hanno messo in evidenza la centralità e l'importanza del chiostro. La complessità del manufatto architettonico ha richiesto l'integrazione di differenti strumentazioni di rilievo per una accurata ricostruzione della geometria. Sempre più spesso, infatti, per gli edifici storici vengono utilizzate tecnologie TLS e UAV, al fine di creare un massivo quantitativo di dati che permetta la revisione degli elaborati grafici, siano essi recenti o datati [Bolognesi, Fiorillo 2019, pp. 193-200]. Inoltre, le nuvole di punti infatti permettono di avere una base di dati consistente sul quale poi poter ricostruire sia modelli tridimensionali realistici che database 
relazionali [Scandurra et al. 20 I8, 1037- 1044). È stata realizzata una campagna di rilievo su tutto il complesso, focalizzandosi una parte delle attività sul chiostro, in modo tale da poter collegare quelle successive; sono state così acquisite 40 scansioni con un laser scanner terrestre, modello Faro Focus S70, e oltre 450 fotografie con il drone DJI Spark, il cui peso è minore di 300g. I dati raccolti hanno permesso una ricostruzione generale dell'architettura in esame; si è quindi deciso di eseguire le ulteriori studi specifici sugli affreschi parietali del chiostro. Per fare questo, sono state scattate I 32 fotografie con Nikon D3200 provvista di opportuno cavalletto, in modo tale da preservare al meglio la complessità e gli aspetti cromatici delle decorazioni in esame (fig. 4). Per ottenere risultati adeguati, le attività di rilievo hanno interessato le prime ore della giornata, in modo tale che il sole non colpisse le zone interessate e ci fosse una condizione uniforme di luce. Attraverso fotogrammetria digitale, è stato possibile ricostruire quattro ortofoto relative alle decorazioni parietali; gli affreschi che interessano le volte sono stati invece analizzati solo attraverso lo studio della nuvola di punti precedentemente costruita dai dati del laser scanner.

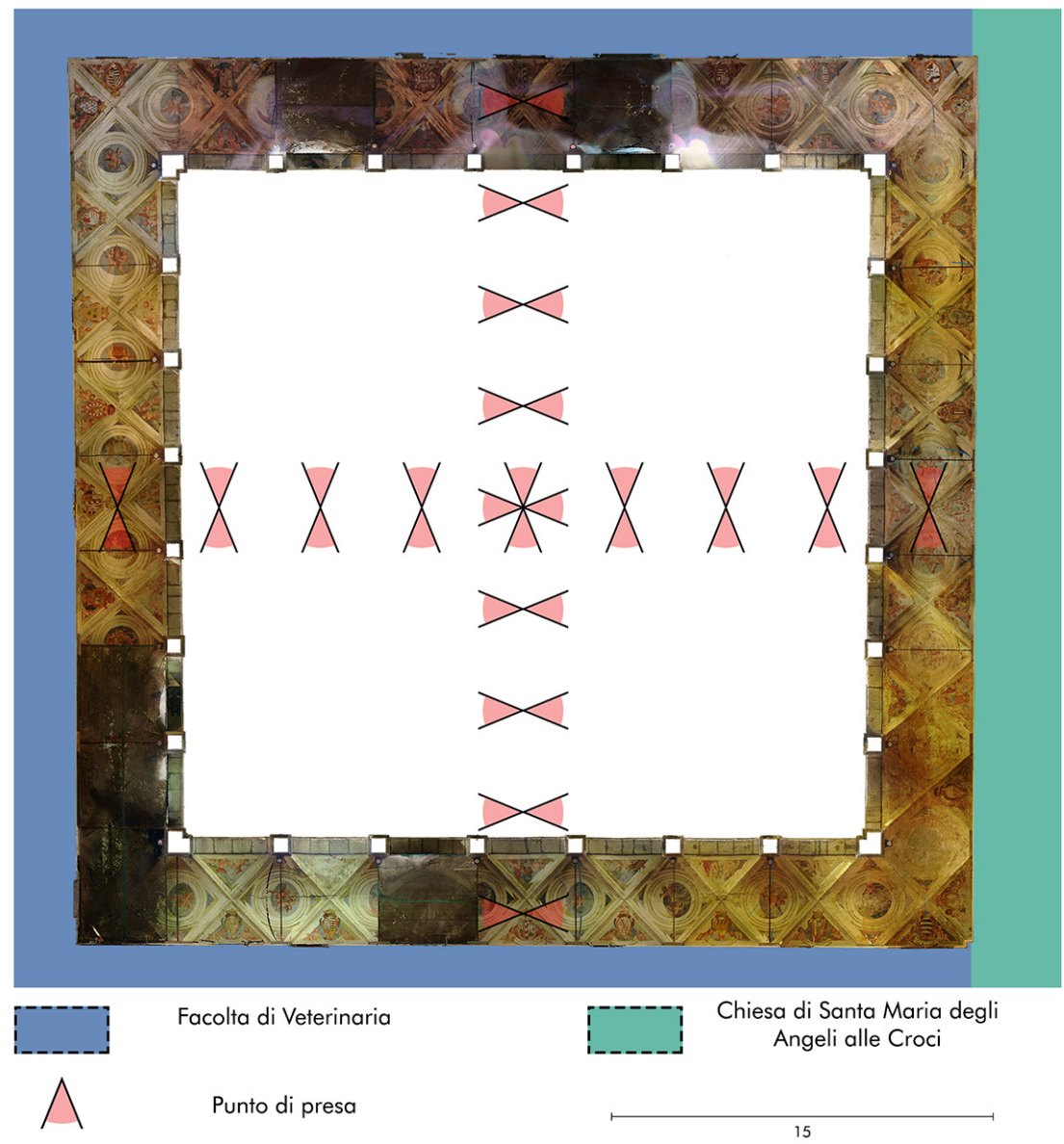

\section{Analisi del chiostro e del suo stato conservativo}

Come precedentemente descritto, il chiostro si trova in una posizione baricentrica e collega l'ala moderna dell'università con la chiesa; esso si sviluppa su una pianta quadrata di lato $34,50 \mathrm{~m}$ e vi insistono 32 volte a crociera, che si ergono poggiandosi sui muri perimetrali e sulle colonne quadrate. Esso presenta decorazioni lungo tutto lo sviluppo della copertura voltata e parzialmente sulle pareti; queste ultime sono interessate solo nella parte alta da affreschi, la cui una quota di imposta è di $2.85 \mathrm{~m}$ dalla quota media del pavimento. In particolare, dei quattro muri perimetrali, uno è in comune con l'edificio ecclesiastico ed è 
quello che presenta affreschi per tutta la sua lunghezza, a differenza delle altre tre pareti, sulle quali le decorazioni mancano in corrispondenza di aperture; in totale sono 27 affreschi e rappresentano episodi tratti dalle sacre scritture (fig. 5). Sulle volte invece sono raffigurati dei putti in scene differenti: nella zona adiacente alle pareti perimetrali, essi sostengono degli stemmi delle famiglie aristocratiche che hanno contribuito al rinnovamento del complesso. Nella zona centrale, ovvero quella individuabile dall'intradosso continuo della volta a botte, vi sono dei medaglioni all'interno dei quali i putti svolgono diverse attività. Infine, nella zona delimitata dalle unghie che poggiano sui pilastri, vi sono solitamente due putti che completano la composizione (fig. 6). Delineate quindi le peculiarità del chiostro, si è passati ad una analisi preliminare del suo stato conservativo; anche in questo caso bisogna diversificare le superfici piane da quelle curve. Sulle pareti è possibile individuare per lo più l'assenza di materiale, in particolare in corrispondenza della zona di confine con la chiesa, e di informazioni colorimetriche, specialmente nella zona in prossimità del lato adiacente all'ala moderna. Lo stato conservativo delle volte risulta più grave: oltre alle perdite di materiale e di informazioni compositive e colorimetriche, sono visibili lesioni la cui estensione non è trascurabile. Per alcune volte, è stata prevista una rete di protezione per evitare che la caduta di detriti possa generare disagi e ostacoli alla normale fruizione degli spazi, oltre ai pericoli ad essa collegati.

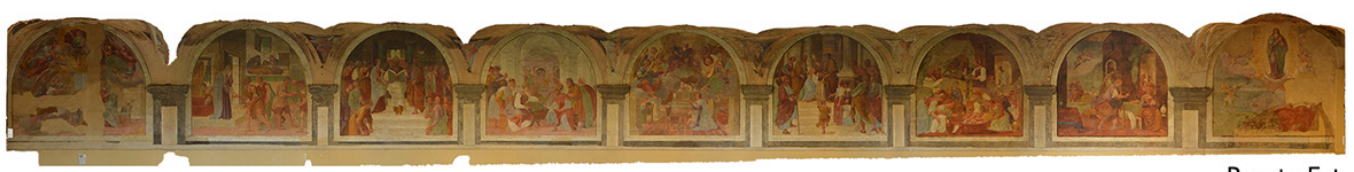

Parete Est

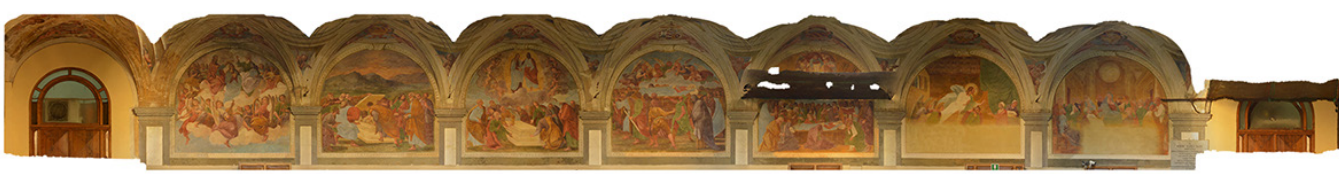

Parete Sud

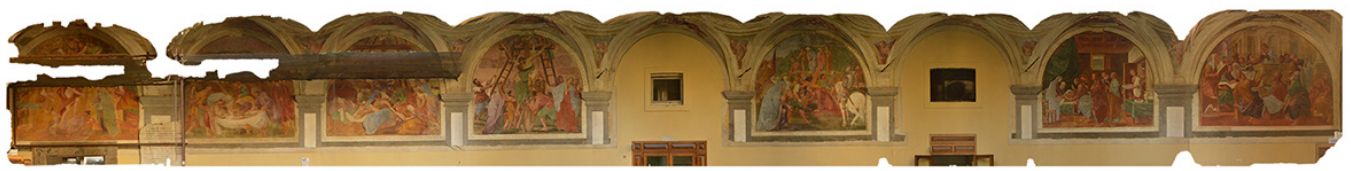

Parete Ovest

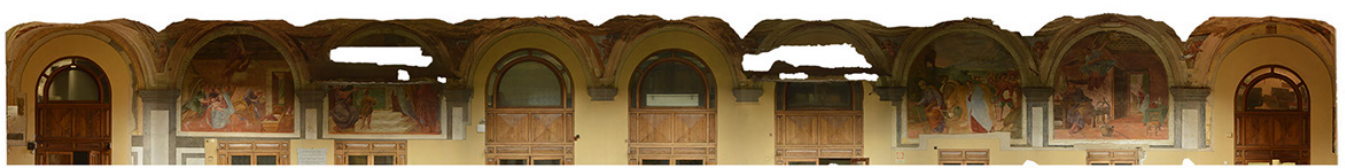

Parete Nord

\section{Database relazionali al servizio della conservazione dell'architettura}

In seguito alle ricerche svolte sul manufatto, che hanno interessato aspetti multidisciplinari, è sorta la necessità di catalogare i dati e renderli fruibili. Se le prime attività di rilievo erano state svolte per rispondere alle esigenze dell'ufficio tecnico, è nata la necessità di raccogliere maggiore documentazione in merito agli apparati decorativi, in modo da preservare la loro qualità artistica e stabilire lo stato di conservazione. Nella loro eterogeneità, tutte le informazioni devono però convergere in un database, dove non siano semplicemente archiviate, ma che diventino utili alla gestione del complesso. II database deve quindi poter comprendere sia campi che descrivano la geometria e la posizione nello spazio sia altri che possano includere informazioni manutentive e quelle storiche, quali ad esempio le vedute e le piante ritrovate. Vista la mole di dati e le necessità espresse dagli uffici, si è deciso di creare un 
sistema di database, che includesse tutte le informazioni e che non risultassero ridondanti. In una prima fase di lavoro si è deciso di costruire un modello BIM, all'interno del quale verranno associate tutte le specifiche metriche e colorimetriche agli oggetti, oltre a quelle sui materiali e sul degrado. In questo modo, il modello diverrebbe il contenitore di tutte informazioni relative all'edificio, utili alla sua manutenzione e gestione del singolo manufatto. Se da un lato l'ambiente BIM risponde anche alla richiesta specifica di aggiornamento dei grafici, da un'altra parte diviene inefficace quando si pensa al complesso all'interno di un sistema interconnesso di luoghi e funzioni, come il caso dell'edificio universitario a carattere storico. Nasce quindi la necessità di creare un ulteriore database degli edifici universitari, che includa le informazioni documentali ma che conservi alcune anche quelle relative ai singoli edifici, seppure ponendosi ad una scala di riferimento territoriale. Si è quindi deciso di creare un database relazionale basato su una piattaforma GIS, che permette di gestire aspetti multidisciplinari e multiscalari: si viene così a creare un sistema di database che può essere interrogato e analizzato. Le informazioni contenute riguarderebbero non solo gli aspetti storico-artistici, ma anche la possibilità di programmare la manutenzione degli edifici. I due database sono autonomi nella loro definizione e nelle loro funzioni, ma condividono alcuni dati: in particolare alcuni campi del modello BIM, opportunamente scelti, verranno importati all'interno del database GIS per semplificare le operazioni di programmazione di manutenzione e gestione degli edifici. Al contempo nel GIS, verrebbero raccolti i dati storici, così da poterli in un secondo momento condividere con enti interessati alla valorizzazione del contesto.
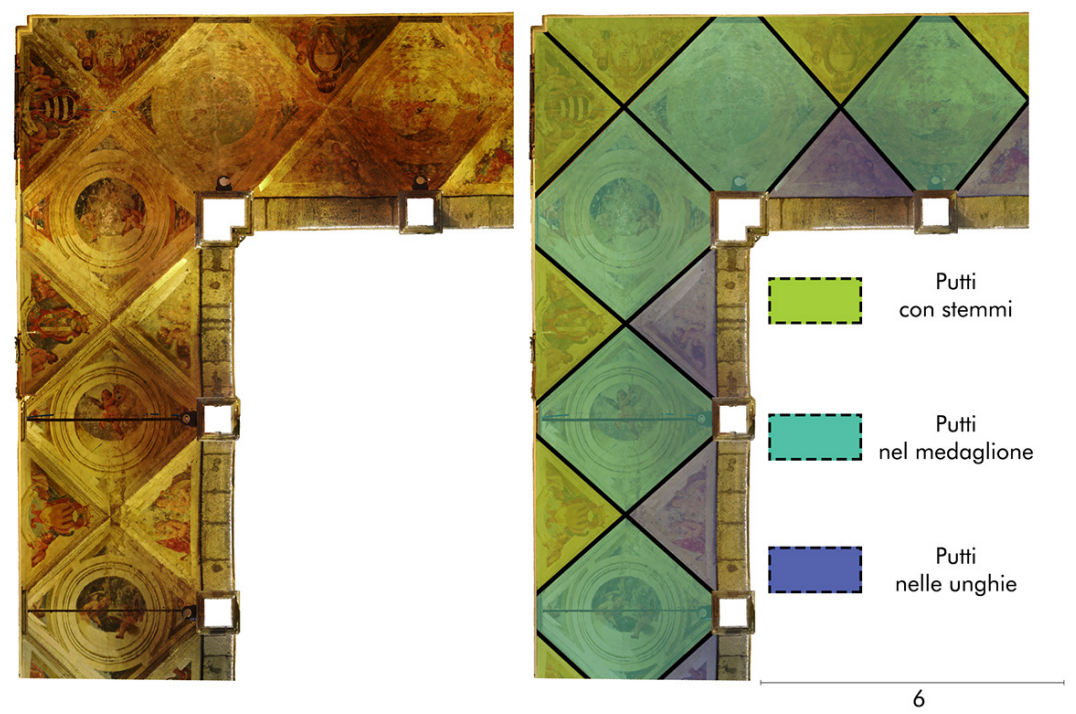

\section{Conclusioni}

Svolgere approfondite ricerche sul tessuto storicizzato rappresenta la prima fase per la conservazione dei luoghi: bisogna contemplare attività eterogenee e multidisciplinari, che servono a ricostruire una immagine quanto più affidabile possibile del patrimonio in esame. Fra le varie attività, il rilievo laser scanner e quello fotogrammetrico non solo permettono di avere modelli digitali attendibili, ma definiscono un punto fermo nella evoluzione del contesto. II risultato così ottenuto deve essere archiviato, prevedendo anche la possibilità che i dati raccolti siano utilizzati per ulteriori scopi. Nasce quindi la necessità di creare database affidabili, che siano differenziati a seconda dello scopo che si vuole raggiungere: a loro volta, questi devono essere mutuamente connessi e devono prevedere campi che consentano di svolgere analisi incrociate, al variare della scala di interesse. Un sistema di database relazionali permetterebbe quindi caratterizzare al meglio i singoli elementi, rappresentati dai singoli edifici, definendo differenti livelli di informazioni. La struttura di questi database deve 
Fig. 7. Dettagli delle decorazioni: un affresco parietale (a sinistra) e un parietale (a sinistra) e un (a destra). prevedere l'integrazione di elementi semanticamente validi e dati non grafici correlati; essi devono inoltre essere facilmente consultabili e aggiornabili. Se singolarmente utilizzate, le metodologie BIM e GIS rispondono solo parzialmente al variare delle esigenze; un utilizzo congiunto di questi sistemi può invece semplificare la visualizzazione e l'analisi di tutte le informazioni e al contempo ottimizzare la gestione del patrimonio edilizio attraverso connessioni collegamenti tra le banche dati. In questo modo, si potranno semplificare le attività di programmazione e progettazione di interventi di manutenzione e di ristrutturazione, con un conseguente risparmio di risorse da parte degli enti coinvolti.
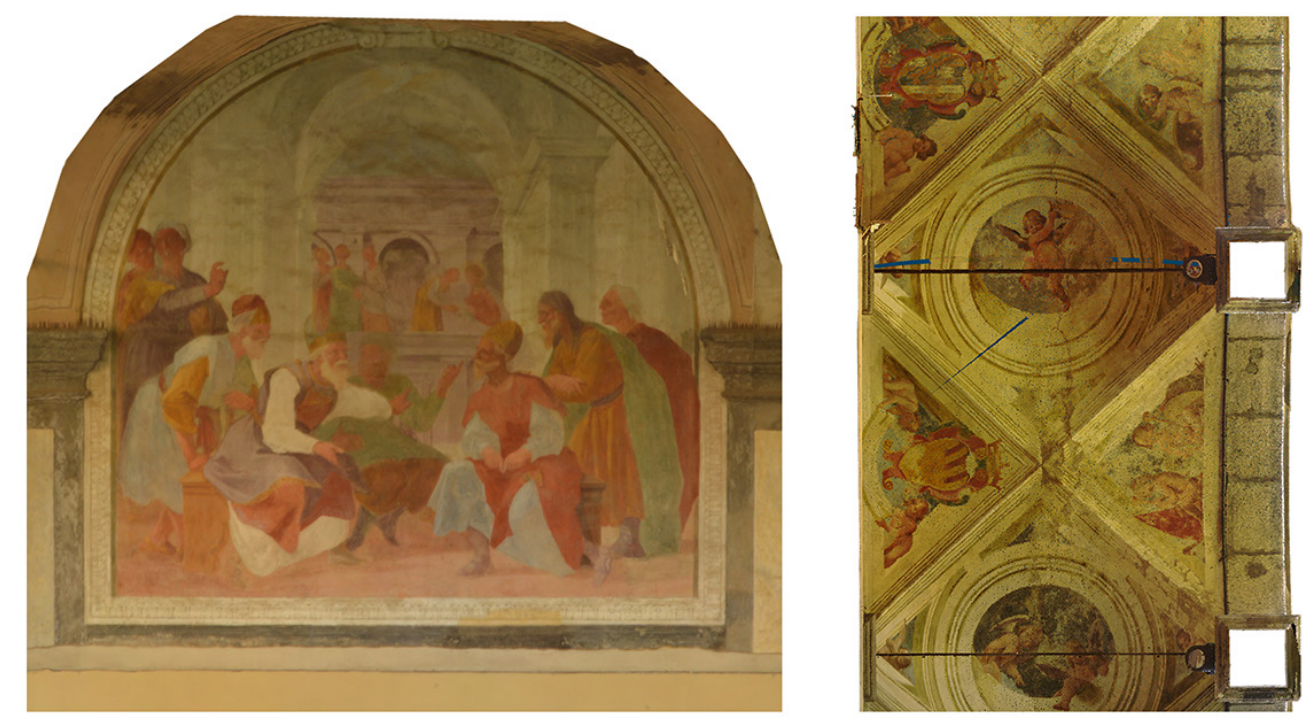

\section{Riferimenti bibliografici}

Baculo Adriana, Florio Riccardo, Rino Fulvio (1992). Napoli in Assonometria. Napoli: Electa, Tav. I5.

Bolognesi Cecilia Maria, Fiorillo Fausta (2019). Digital survey in Bramante's Masterpiece. In Int. Arch. Photogramm. Remote Sens. Spatial Inf. Sci., XLII-2M I 5, 2019, pp. 193-200.

Comune di Napoli, PRG 1939, Fog. 17, http://www.comune.napoli.it/flex/cm/pages/ServeBLOB.php/L/IT/IDPagina/I4374

de Seta Cesare (1969). Cartografia della città di Napoli. Napoli: Edizione Scientifiche Italiane, Vol. I, pp. I2I - I 37.

de Seta Cesare (1969). Cartografia della città di Napoli. Napoli: Edizione Scientifiche Italiane, Vol 2, Fog. XVII, XXIII, XXVIII.

de Seta Cesare (1969). Cartografia della città di Napoli. Napoli: Edizione Scientifiche Italiane, Vol 3.

Firrao Cesare, Schiavoni Federico, Orsini Raffaele, Lauria Ercole (1992). Pianta dello Schiavoni. Napoli: Elio De Rosa, Tav. 8.

Fratta Arturo, Giordano Riccardo (2004). Il patrimonio architettonico dell'Ateneo fridericiano. Napoli: Arte tipografica, pp. 299. 321 .

Pugliese Caratelli Giovanni (1994). Storia e Civiltà della Campania. II Rinascimento e l'età Barocca. Napoli: Electa, pp. 356-38I.

Scandurra Simona, Pulcrano Margherita, Cirillo Vincenzo, Campi Massimiliano, di Luggo Antonella, Zerlenga Ornella (20I8) Integrated survey procedures for the virtual reading and fruition of historical buildings. In Int. Arch. Photogramm. Remote Sens. Spatial Inf. Sci., XLII-2, 20 I8, pp. I037-1044.

\section{Autore}

Carlo Giannattasio, Università degli Studi di Napoli “Federico II", carlo.giannattasio@unina.it

Per citare questo capitolo: Giannattasio Carlo (2020). Connessioni digitali per la salvaguardia dell'architettura di pregio/Digital connections for the preservation of valuable architecture. In Arena A., Arena M., Brandolino R.G., Colistra D., Ginex G., Mediati D., Nucifora S., Raffa P. (a cura di). Connettere. Un disegno per annodare e tessere. Atti del $42^{\circ}$ Convegno Internazionale dei Docenti delle Discipline della Rappresentazione/Connecting. Drawing for weaving relationships. Proceedings of the 42th International Conference of Representation Disciplines Teachers. Milano: FrancoAngeli, pp. 2276-229 | 


\section{Digital Connections for the Preservation of Valuable Architecture}

Carlo Giannattasio

Abstract

The reconstruction and recovery process of a historicized architectonic context requires a careful analysis of the individual buildings it is composed of. Documentary researches must be performed along with multiple survey campaigns to accurately define the conservative state of the artifact. The massive acquisition of heterogeneous data may be vane if the information storage and management procedures are not adequately defined. We present here some preliminary results of the research carried out on the complex of Santa Maria degli Angeli alle Croci, located in Naples. In detail, after delineating the transformations suffered by the building, the compositive scheme and the conservation state of the frescoes in the cloister were analyzed. We also wanted to highlight the need for relational databases and a process that involves a combined use of the BIM and GIS methodologies.

Parole chiave

database, architecture, survey, BIM-GIS, connection.

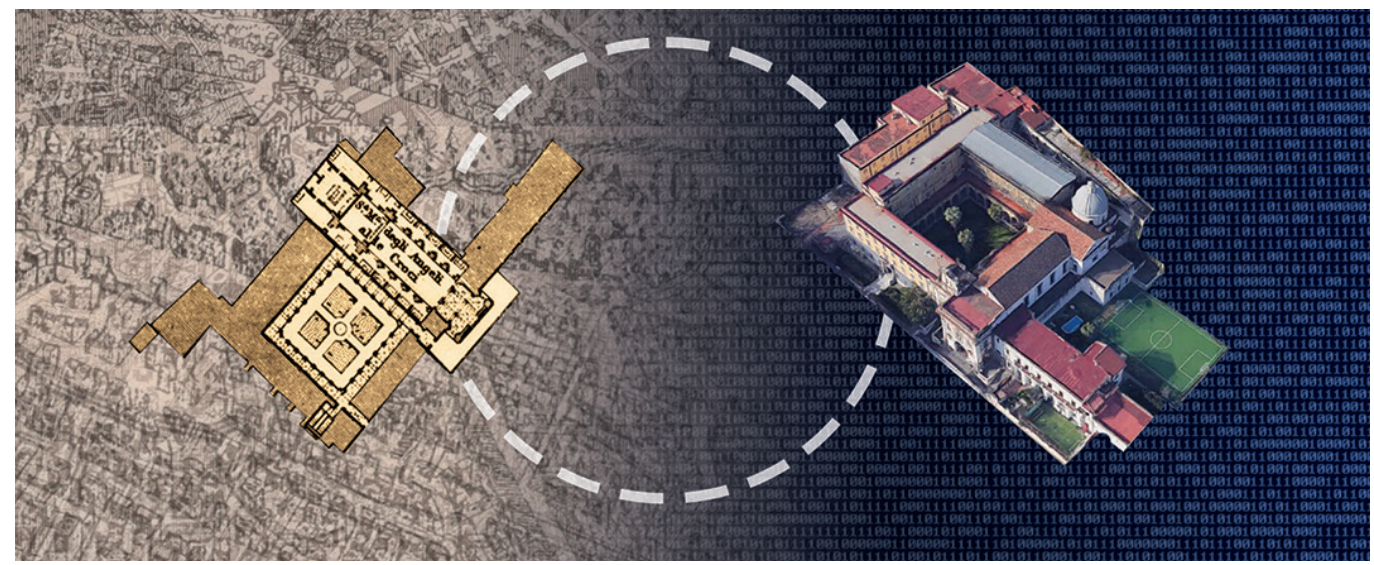




\section{Introduction}

The persistent renovation of the urban building fabric led to the creation of stratified buildings and these traces are likely to get lost if not properly documented and preserved. The constant changing, both structural and functional, may damage and cancel the relics, making them unrecoverable. With the new digital technologies, it is possible to link the knowledge and create databases in which collect and share all the information. Albeit only in a digital way, the rebuilding of these places has the purpose to create a starting point for an awareness process; the spreading of the researches may, in fact, result in a recovery procedure of complexes and small centers. Therefore, it is crucial to have an appropriate procedure of data storage and management, which, later, may kick subsequent interventions, may they be structural or only communicative ones. The study presented here shows the evolution of an architectonic artifact, located in Naples. In detail, we carried out the survey and analysis of the decorative apparatus of the Santa Maria degli Angeli alle Croci complex; a part of the building hosts the Veterinary School of the University of Naples Federico II. We also wanted to define a data storage and management process using a relational database system.

Fig. I. Identification of the complex of Santa Maria degli Angeli alle Croci on historical drawings: a) View of 1685 [de Seta 1969, XVII]; b) View of 1720 (de Seta 1969. XXIII); c) Gravier plan of 1775 [de Seta 1969 $X X V I I I] ;$ d) Duke of Noja plan of 1775 [de Seta 1969, vol III].



\section{Historical-compositive evolution of the building}

Santa Maria degli Angeli alle Croci was built in the late 16th century and, during this period, Neaples experienced many changes. In the first half of the 1500s, the city suffered a huge demographic expansion, that continued in the second half, albeit in a minor way. This prompted a growth of the city outside the borders, mainly driven by wealthy individuals or by different religious orders; the latter, in particular, settled in Naples thanks to the support of the Church and the protection of the Spanish government. Following this expansion, the Santa Maria degli Angeli alle Croci complex was built for the will of the Observant Franciscans and it originally consisted of a church and a convent [de Seta 1969, pp. I 2 I - I37]. It was located outside the city limits, in the north-east area, together with other new religious and non-religious complexes. The architectural artifact was restored before the first half of the 1600s, (1639-1647), by Cosimo Fanzago. It is fundamental to underline the participation of Belisario Corenzio and his co-workers in the restructuring: they were entrusted with the task of frescoing the cloister inside the convent [Pugliese Caratelli 1994, pp. 356-38 I]. If a first illustration of the building can be retrieved in 1600 and 1720 drawings, more information on its conformation can be obtained from the floor plans of Gravier and, above all, from that of the Duke of Noja (fig. I). In particular, in the representation of the Duke of Noja, the conformation of the two buildings, the church and the convent, is delineated: they have a wall in common, in correspondence of the inner cloister. At the beginning of the 19th century, Naples suffered a series of transformations, including the Napoleonic suppression of religious orders: with this measure, some properties owned by the Church were used for new functions. The complex of Santa Maria degli Angeli alle Croci fell among them: the church remained under the management of the friars, but the convent became an institute of veterinary medicine, with theoretical and practical teachings [Fratta 2004, pp. 299-32 I].
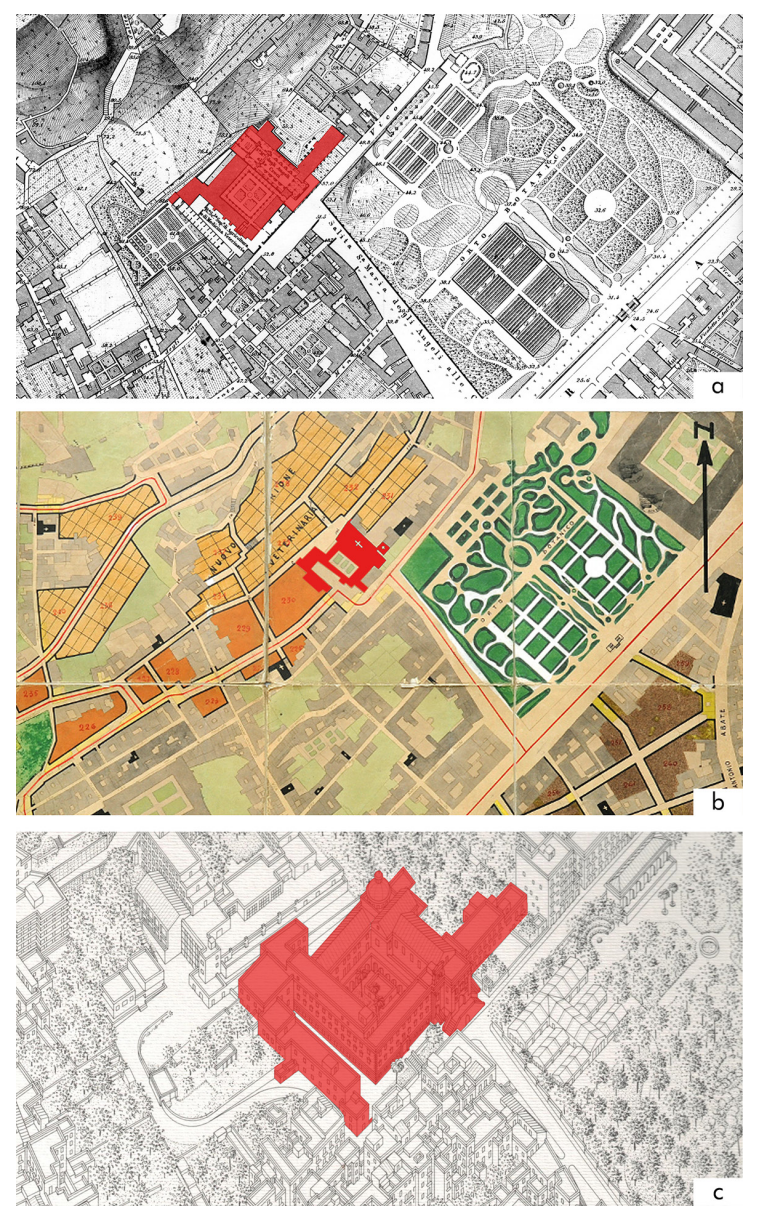
This change of use is also reported later in the Schiavoni plan (fig. 2a) which distinguishes the church from the Reale Scuola Superiore di Agricoltura e di Medicina Veterinaria (Royal Higher School of Agriculture andVeterinary Medicine). In the first half of 1900, the structure was extended and modernized, as can also be seen from the PRG (land-use plan) tables of 1939 (fig. 2b): in the same period, it was annexed to the University of Naples Federico II. In the years following the Second World War, further enlargements were made to the area that was previously used as stables (fig. 2c). Its image remained almost unchanged until in 20 I 5 when the complex became sadly known for a tragic event: in a December morning, part of the modern wing collapsed due to a subsidence of the subsoil. The current architectural structure can be divided, therefore, into three parts: the church, the former convent and the modern wing. The ecclesiastical building is made up of a single central nave, containing some vaulted chapels on its sides; however, it does not contain any valuable or decorative elements inside. The university block has a heterogeneous structure, which depends on the period of construction of the single buildings. Arranged on four levels, the former convent preserves the traces of the original structure, even if it suffered many transformations: the cloister is still the fulcrum around which the whole building is developed. This element remained almost unchanged, as highlighted by historical plans and construction elements (masonry structures and vaulted roofs). Again on four levels, the twentieth-century wing was adapted to the pre-existing volume, preserving the main elevations and the existing stringcourses; however, the structure is composed of elements framed in reinforced concrete, respecting the dictates of the time.

Fig. 3. Three-dimensional view from satellite photos of the complex of Sant Maria degli Angeli alle Croci.

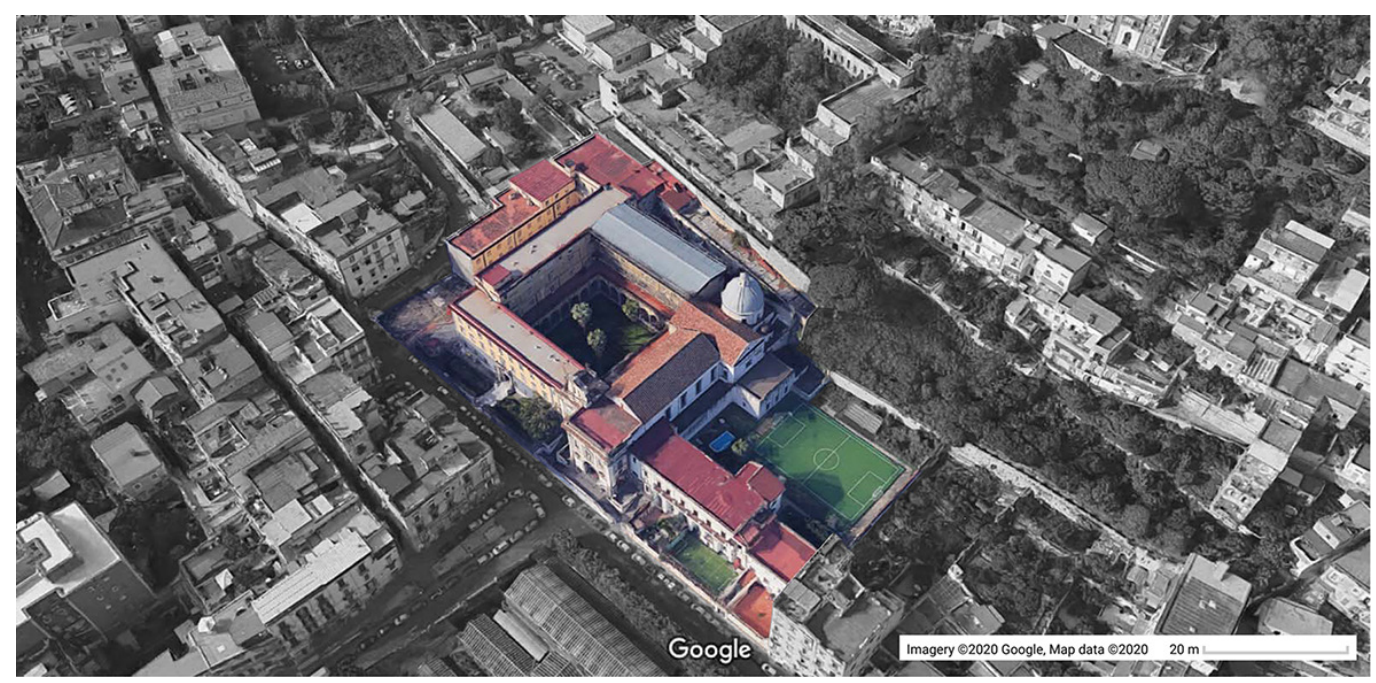

\section{Report of survey activities}

Following the tragic event of 2015 , the University's technical office requested to update and detail the graphs contained in the archive. The data in their possession, in fact, could not describe the architectonic complexity of the building. However, the technical drawings were useful in planning and design the survey activities. An initial inspection was, then, carried out in order to identify the areas from which to start the survey activities. The centrality and importance of the cloister was highlighted by the analysis previously conducted and by the conservative necessity of the decorative apparatus. A survey campaign was realized on the whole complex, focusing a part of the activities on the cloister, in order to interconnect the following ones; 40 scans were acquired with a terrestrial laser scanner, model Faro Focus S70, and over 450 photographs with a drone DJI Spark, which weighs less than 300g. The 
data collected permitted a general reconstruction of the architecture in under consideration; therefore, we decided to perform further detailed studies on the wall frescoes of the cloister. I 32 photographs were taken for this purpose with Nikon D3200 equipped with a tripod, in order to better preserve the complexity and chromatic aspects of the considered decorations (fig. 4). In order to obtain adequate results, the survey activities were conducted during the first hours of the day, so that the sun did not affect the interested areas and there was a uniform light condition. It was possible to reconstruct four orthophotos of wall decorations through digital photogrammetry; the frescoes on the vaults were, instead, analyzed only through the study of the point cloud previously built by the laser scanner data.

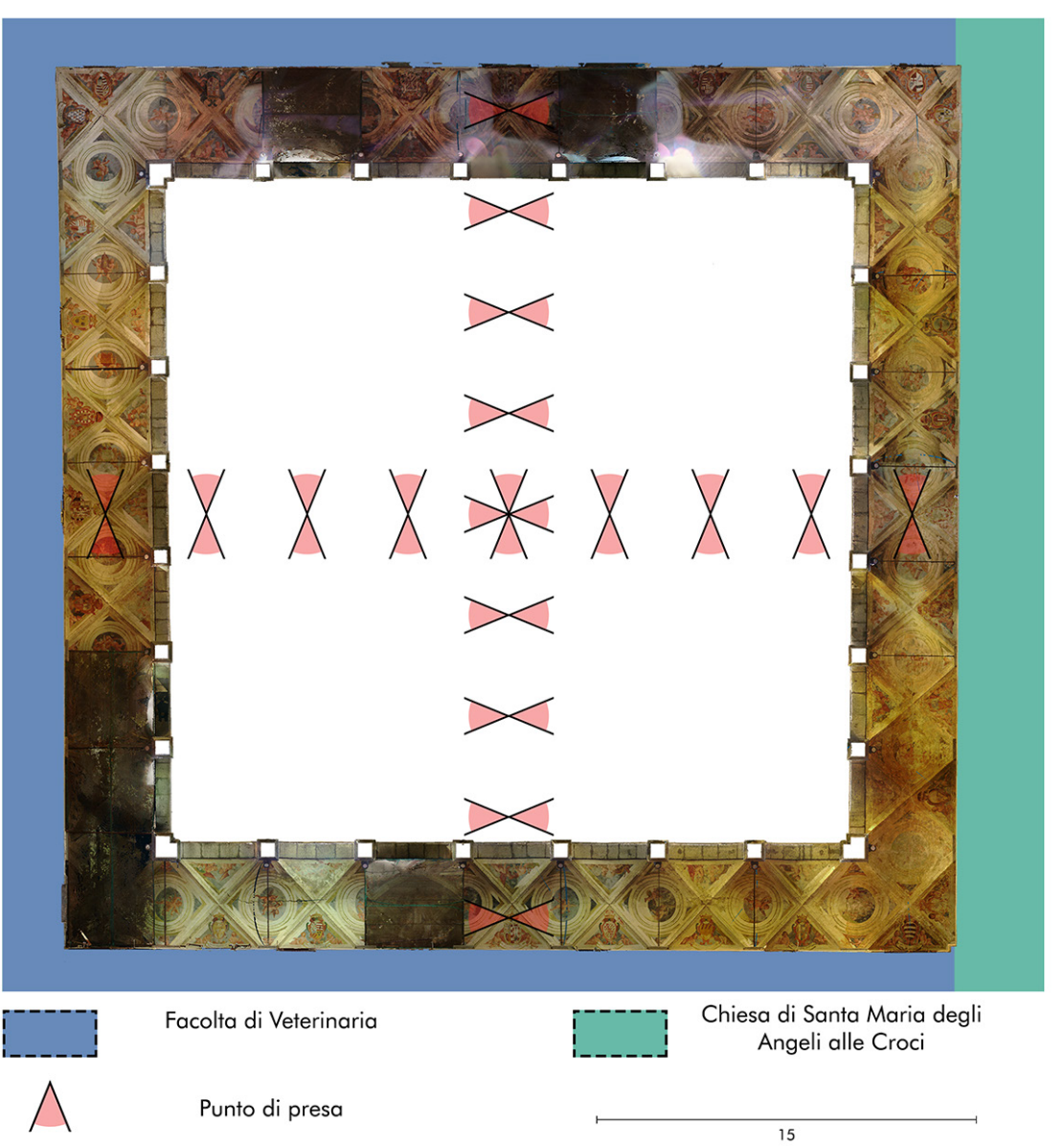

\section{Analysis of the cloister and its state of preservation}

As previously described, the cloister is located in a barycentric position and connects the modern wing of the university with the church; it has a square plan of $34.50 \mathrm{~m}$ per side and 32 cross vaults, which lay on the perimeter walls and square columns. It has decorations on the entire vaulted roof and partially on the walls. The walls are only affected in the upper part by frescoes, the height set of which is $2.85 \mathrm{~m}$ from the average height of the floor. In particular, of the four perimeter walls, one is in common with the ecclesiastical building and is the one that has frescoes along its entire length, unlike the other three walls, on which the decorations are missing in correspondence of openings. In all, there are 27 frescoes that represent episodes from the Scripture (fig. 5). On the vaults, on the other hand, putti are portrayed in different scenes. In the area adjacent to the perimeter walls, they support the 
coats of arms of the aristocratic families who contributed to the renewal of the complex. In the central area, which can be identified by the continuous intrados of the barrel vault, there are medallions within which the putti perform different activities. Lastly, in the part delimited by the groin vault standing on the pillars, there are usually two putti that complete the composition (fig. 6). After delineating the peculiarities of the cloister, we moved on to a preliminary analysis of its conservation state; it is necessary to diversify the flat surfaces from the curved ones also in this case. On the walls, it is possible to identify the absence of material, especially in the area bordering the church, and of colorimetric information, especially in the area near the side adjacent to the modern wing. The conservative state of the vaults is more serious: there are visible creeps whose extent is not negligible, in addition to the loss of material and compositional and colorimetric information. For some vaults, a safety net was installed to avoid that the fall of debris could cause discomfort and obstacle the normal use of the spaces, in addition to the dangers connected to it.
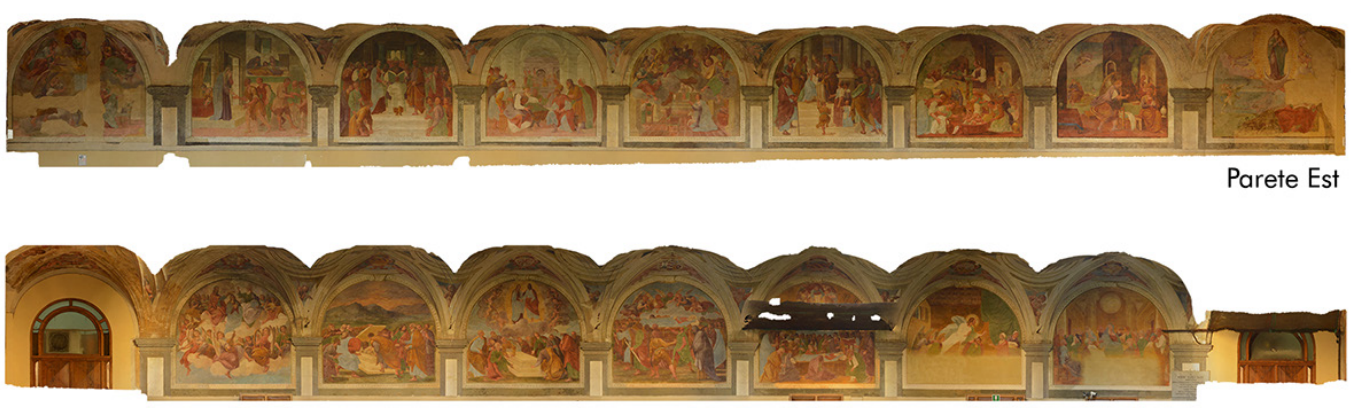

Parete Sud
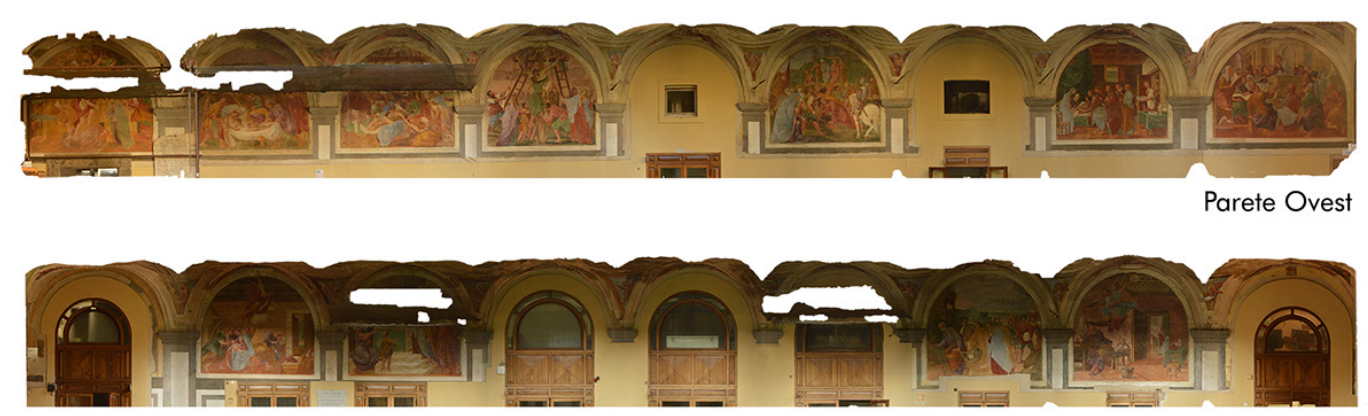

Parete Nord

\section{Relational databases for the preservation of architecture}

As a result of the research carried out on the building, which involved multidisciplinary aspects, it became necessary to catalog the data and make them usable. If the first survey activities were conducted to respond to the needs of the technical office, there was a necessity to collect more documentation about the decorative apparatus, in order to preserve their artistic quality and establish their state of conservation. In their heterogeneity, however, all the information must converge in a database, where it is not simply stored, but becomes useful for the management of the complex. The database must, therefore, be able to include both fields that describe its geometry and its position in the space, as well as other fields that may include both maintenance and historical information, such as views and floor plans found. We decided to create a system of databases, which would include all the information and would not be redundant, given the amount of data and the requirements expressed by the offices. In the first phase of work, we decided to build a BIM model, within which all the 
Fig. 6. Orthophoto detail of the vaulted ceiling (left) with the composition scheme (right). metric and colorimetric specifications will be associated with the objects, as well as those on materials and degradation. In this way, the model would become the repository of all the information related to the building, which is useful for its maintenance and management. If, on one hand, the BIM environment also responds to the specific request to update graphs, on the other hand, it becomes inefficient when one thinks of the complex within an interconnected system of places and functions, as in the case of the historical University building. Therefore, it becomes necessary to create an additional database of University buildings, which includes documentary data, but also preserves some of the information of the individual buildings, albeit at a territorial reference scale. Considering this, we decided to create a relational database based on a GIS platform, which allows managing multidisciplinary and multiscalar aspects: in this way, a database system that can be queried and analyzed is generated. The information contained would concern not only the historical-artistic aspects but also the possibility of planning the maintenance of the buildings. The two databases are autonomous in their definition and functions, but they share some data: in particular, some fields of the BIM model, appropriately chosen, will be imported into the GIS database to simplify maintenance and building management planning operations. At the same time, in the GIS, historical data would be collected, so that they could be shared, at a later stage, with institutions interested in enhancing the context.
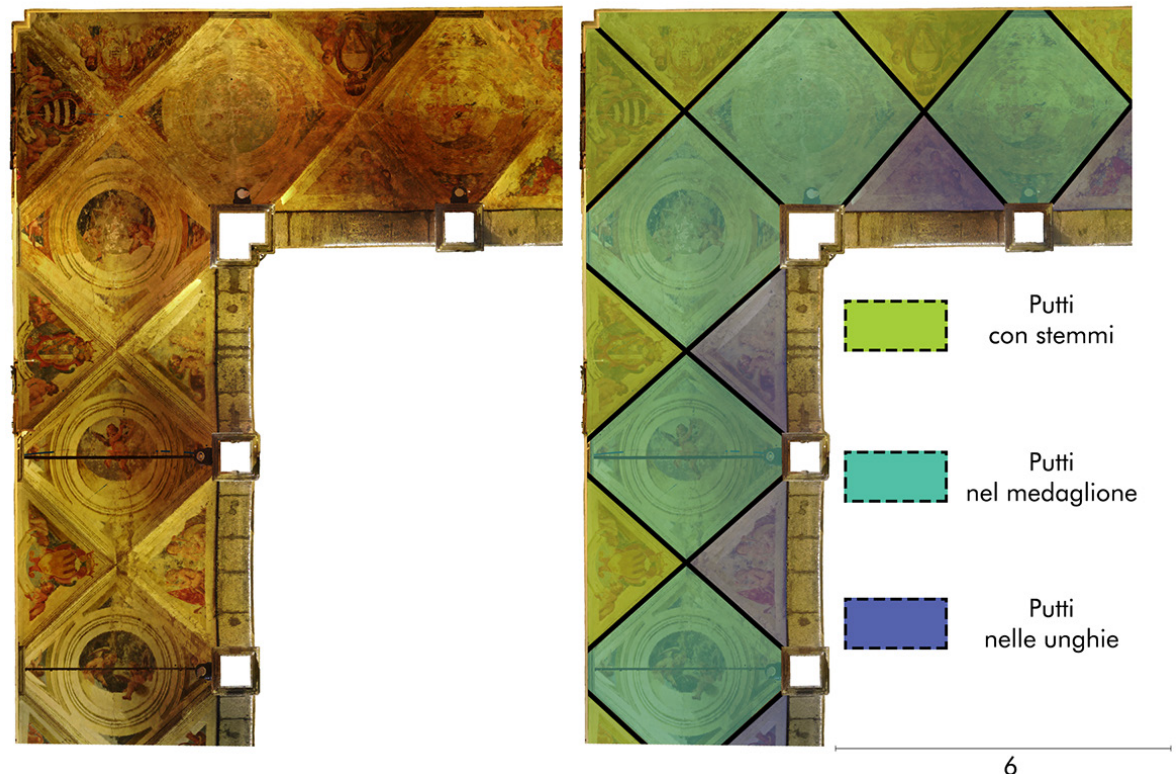

\section{Conclusion}

Performing detailed research on the historicized contexts represents the first phase for the conservation of buildings: heterogeneous and multidisciplinary activities must be contemplated, which serve to reconstruct an image as reliable as possible of the considered heritage. Among the various activities, laser scanner and photogrammetric survey not only allow us to have reliable digital models but also define a fixed point in the evolution of the context. The results obtained must be archived, including the possibility that the data collected may be used for further purposes. Therefore, it is necessary to create reliable databases that are differentiated according to the final purpose: these, in turn, must be mutually interlinked and must provide fields that allow performing cross-analysis as the scale of interest changes. A system of relational databases would, therefore, allow to better characterize the single elements, represented by the individual buildings, defining different levels of information. If used 
individually, the BIM and GIS methodologies only partially respond to varying requirements; joined use of these systems can, instead, simplify the visualization and the analysis of all the information and, at the same time, optimize the management of the building stock through connections between databases.

Fig. 7. Details of the decorations: a wall fresco (left) and a detail of the vaults (right).
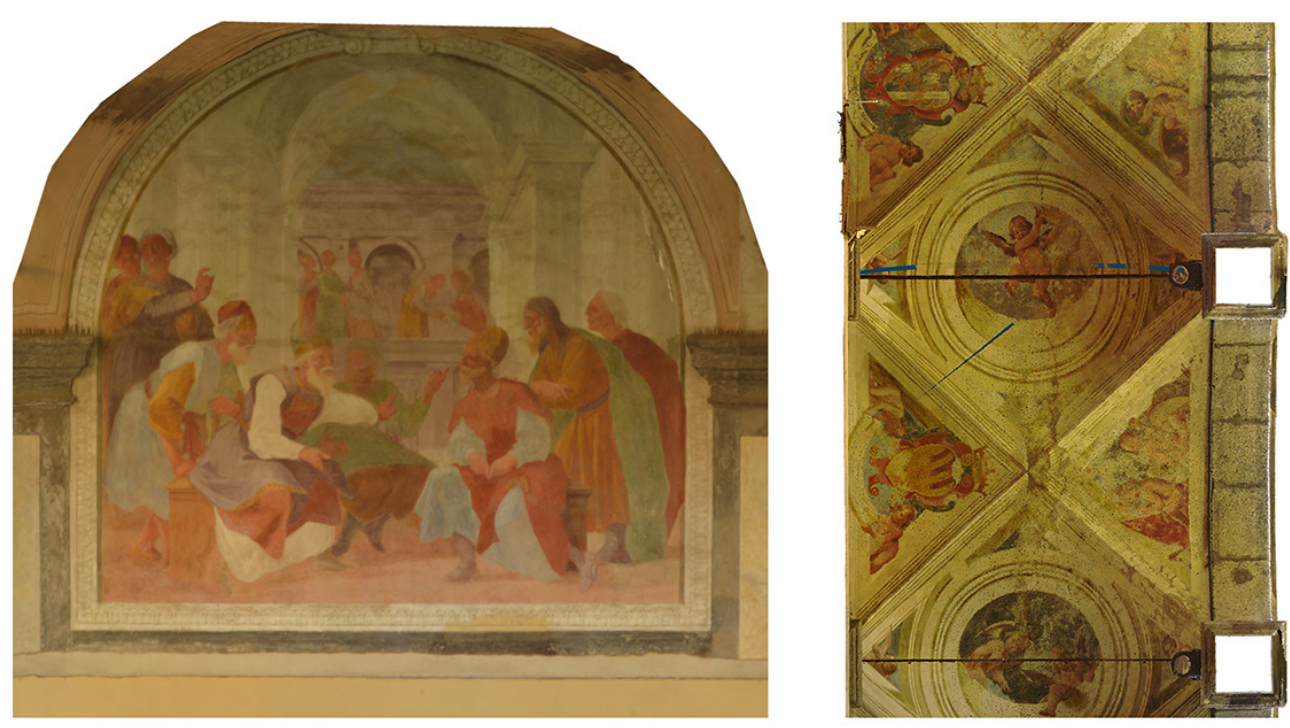

\section{References}

Baculo Adriana, Florio Riccardo, Rino Fulvio (1992). Napoli in Assonometria. Napoli: Electa, Tav. 15.

Bolognesi Cecilia Maria, Fiorillo Fausta (2019). Digital survey in Bramante's Masterpiece. In Int. Arch. Photogramm. Remote Sens. Spatial Inf. Sci., XLII-2MI5, 2019, pp. 193-200.

Comune di Napoli, PRG 1939, Fog. 17, http://www.comune.napoli.it/flex/cm/pages/ServeBLOB.php/L/IT/IDPagina/I4374

de Seta Cesare (1969). Cartografia della città di Napoli. Napoli: Edizione Scientifiche Italiane, Vol. I, pp. I2I - I 37.

de Seta Cesare (1969). Cartografia della città di Napoli. Napoli: Edizione Scientifiche Italiane, Vol 2, Fog. XVII, XXIII, XXVIII.

de Seta Cesare (1969). Cartografia della città di Napoli. Napoli: Edizione Scientifiche Italiane,Vol 3.

Firrao Cesare, Schiavoni Federico, Orsini Raffaele, Lauria Ercole (1992). Pianta dello Schiavoni. Napoli: Elio De Rosa, Tav. 8.

Fratta Arturo, Giordano Riccardo (2004). Il patrimonio architettonico dell'Ateneo fridericiano. Napoli: Arte tipografica, pp. 299. 321.

Pugliese Caratelli Giovanni ( 1994). Storia e Civiltà della Campania. Il Rinascimento e l'età Barocca. Napoli: Electa, pp. 356-38I.

Scandurra Simona, Pulcrano Margherita, Cirillo Vincenzo, Campi Massimiliano, di Luggo Antonella, Zerlenga Ornella (20।8). Integrated survey procedures for the virtual reading and fruition of historical buildings. In Int. Arch. Photogramm. Remote Sens. Spatial Inf. Sci., XLII-2, 2018, pp. 1037-1044.

\section{Author}

Carlo Giannattasio, Università degli Studi di Napoli “Federico II”, carlo.giannattasio@unina.it

To cite this chapter: Giannattasio Carlo (2020). Connessioni digitali per la salvaguardia dell'architettura di pregio/ Digital connections for the preservation of valuable architecture. In Arena A., Arena M., Brandolino R.G., Colistra D., Ginex G., Mediati D., Nucifora S., Raffa P. (a cura di). Connettere. Un disegno per annodare e tessere. Atti del $42^{\circ}$ Convegno Internazionale dei Docenti delle Discipline della Rappresentazione/Connecting. Drawing for weaving relationships. Proceedings of the 42th International Conference of Representation Disciplines Teachers. Milano: FrancoAngeli, pp. 2276-2291. 